\title{
Article
}

\section{Go-go dancing - femininity, individualism and anxiety in the 1960 s}

\author{
Gregory, Georgina
}

Available at http://clok.uclan.ac.uk/25183/

Gregory, Georgina ORCID: 0000-0002-7532-7484 (2018) Go-go dancing femininity, individualism and anxiety in the 1960s. Film, Fashion \& Consumption, 7 (2). pp. 165-177.

It is advisable to refer to the publisher's version if you intend to cite from the work. http://dx.doi.org/10.1386/ffc.7.2.165_1

For more information about UCLan's research in this area go to

http://www.uclan.ac.uk/researchgroups/ and search for <name of research Group>.

For information about Research generally at UCLan please go to http://www.uclan.ac.uk/research/

All outputs in CLoK are protected by Intellectual Property Rights law, including Copyright law. Copyright, IPR and Moral Rights for the works on this site are retained by the individual authors and/or other copyright owners. Terms and conditions for use of this material are defined in the policies page.

\section{CLoK}

Central Lancashire online Knowledge www.clok.uclan.ac.uk

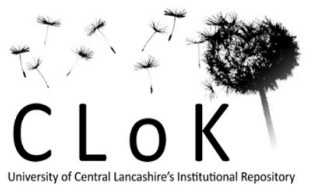




\section{Georgina Gregory, School of Humanities and the Social Sciences, \\ University of Central Lancashire, Preston, Lancashire.}

Email: ggregory@uclan.ac.uk

Go-Go Dancing - Femininity, Individualism and Anxiety in the 1960s

Key words: dance, 1960s, Go-Go, gender, erotic capital

Mainly performed by young women at nightclubs and discotheques, go-go dancing was a high-energy, free-form, dance style of the 1960s. Go-go dancers were employed to entertain crowds and to create a 'cool' ambience, wearing very revealing outfits including mini dresses, short fringed skirts, tank tops, tight shorts and calf length boots. The dance style soon reached mainstream media platforms such as the U.S. television show Hullabaloo and ABC's Shindig, where girls could be seen suspended in clear plastic cages above the dancefloor.

Prior to the Second World War partner dancing was the norm and social dance typically involved close physical contact, often as part of traditional courtship ritual. Moreover most of the earlier dances required men to take the lead and to physically guide their female partner. A striking characteristic of go-go, was the fact that girls usually danced alone, sometimes placed on podiums and often separate from the crowd. In this respect, o-go dancing can be viewed as an extreme extension of a growing trend towards solo dancing..

The article explains how go-go dancing could be seen as reflecting social changes occurring during the 1960s, a time when gradual loss of faith in traditional sources of social guidance religion, government, marriage - saw the rise of greater individualism. Women's growing emancipation and a move towards self-direction was embodied by go-go dancers, whose free style movements and rejection of formal steps, metaphorically embody the dilemma of a generation of women facing an uncertain future. 


\section{The Origins of Go-Go Dancing}

The term 'go-go',describing fast-moving phenomena, was a fitting label for the frenetic form of dancing which surfaced at the height of the economic upswing in the mid-1960s (Oxford Living English Dictionary, 2017). Like the phrase "go-go-go", an expression used to describe a sense of "energy, enthusiasm and vigour", go-go resontated with the overall mood of the 1960s (go-go-go, 2017). It was essentially a high-energy, erotically charged, free-form style of movement, performed mainly but not exclusively, by young women, many of whom danced on raised podiums, or in cages suspended from the ceilings of nightclubs.

Accounts suggest that the go-go style of dancing emerged simultaneously in two American night clubs: The Peppermint Lounge in New York City and a Los Angeles venue, The Whisky a Go-Go. At The Peppermint Lounge the dance evolved from women performing The Twist, another 1960s dance on tables, until gradually their movements became the go-go style (The Twist, 1992). The Whisky a Go-Go which took its name from the fashion for go-go dancing, was immortalized by The Miracles in the 1966 song Going to a Go Go, an inclusive anthem describing the mood of the dance clubs (See Fig. 1) (Hunt, 2009).

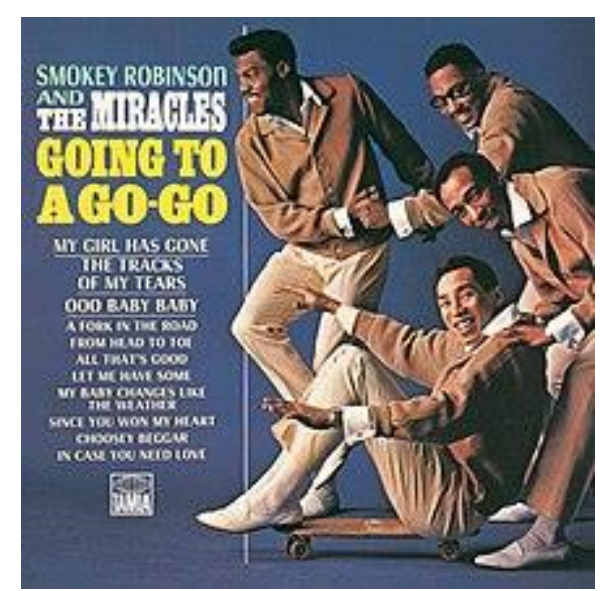

(Fig. 1 The Miracles - Going to a Go-Go)

https://en.wikipedia.org/wiki/Going_to_a_Go-Go\#/media/File:Miraclesgoingtoagogo.jpg 
According to McLellan (2008: B11) go-go dance stemmed from the club's competition to recruit a female DJ to play records in between live sets. When the winner's mother forbade her from accepting the job, a club cigarette girl Patty Brockhurst took on the role, working high above the state in a glass booth. The promoter Elmer Valentine suggests her go-go dancing evolved more by accident than design: "She had on a slit skirt, and we put her up there ... She's a young girl, so while playing the records, all of a sudden, she starts dancing to 'em. It was a dream. It worked"' (Perrone, 2009).

Other girls were soon recruited to perform similar free form moves and before long, the signature fringed dresses, white boots and energetic moves became synonymous with the gogo style itself (Kamp, 2006: ). ${ }^{\mathrm{i}}$ The craze quickly spread, becoming a regular feature on television, notably in Hullabaloo, the NBC network musical variety series, where fashion model Lada Edmund appeared in the 'Hullabaloo A-Go-Go' segment towards the end of the show (Vincent, 1979: 218). The television series Shindig! was another to feature go-go dancers who performed in clear plastic cages, surrounded by lights synchronized to match the rhythm of the music (Austen, 2007: 39).

Like other forms of dance, go-go was able to communicate important messages about women's lives during the period in question, drawing to mind Ted Polhemus's observation that: "At the most fundamental level of analysis, dance, gender and culture are one and the same thing" (Polhemus, 1995:3). During any historical period the dance floor might be viewed as a site where social and cultural issues are negotiated, never more so than in the 1960s when go-go dancing first surfaced as a new style. Amongst other things, go-go symbolized the cultural mood of an epoch dominated by the values of young adults who were keen to reject tradition, expressing their individuality through fashion, music and stylized dance moves (See Fig. 2.) 


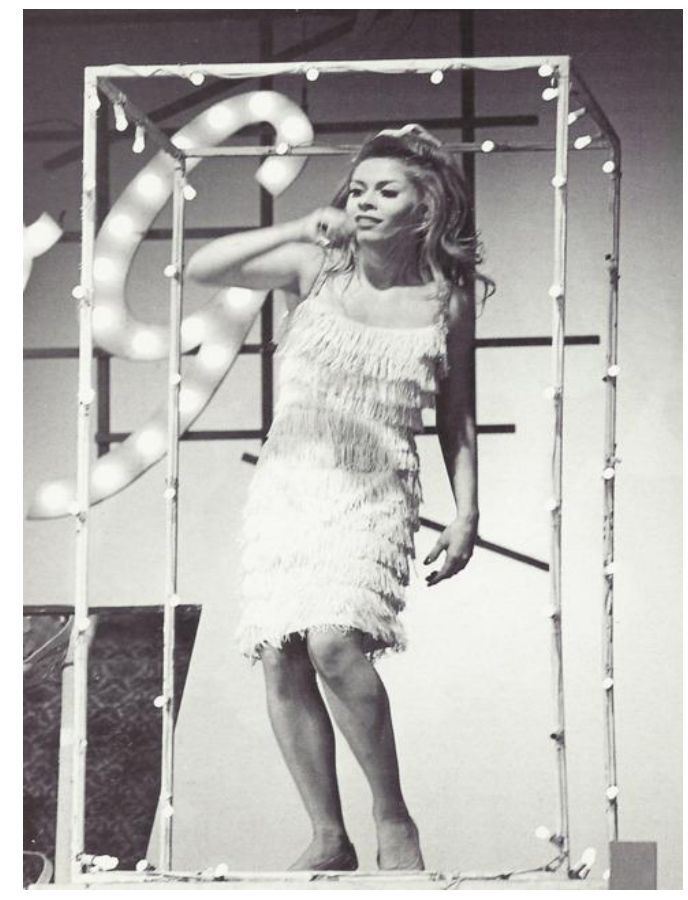

(Fig 2. 1960s go-go dancer),

(source: https://www.tumblr.com/search/1960's\%20go\%20go\%20dancer)

The dance also drew attention to the new found freedom of a generation of women who, having loosened some of the constraints experienced by their precedessors, were entering uncharted territory, Newfound freedom was particularly noticeable in the area of gender relations, where the blossoming women's liberation movement disrupted some of the certainties surrounding sexual relationships, careers and marriage. On the surface, go-go dancing was a fun, liberating and sexy activity enjoyed by young women, and in the popular imagination it epitomizes the very essence of "the swinging sixties". Not only did the style encapsulate the sixties' emphasis on freedom, self-expression and modernity, it also illustrates the resonance of the girl as a cipher within post war mass-media, at which point "images of young, utterly contemporary women . . . became the high-profile subjects of sociological and anthropological studies (Kennedy, 2015: 180).

\section{A Response to Newfound Freedom}


It is striking to note how the women generally danced alone, particularly since throughout the first half of the twentieth century partner dancing was the norm at social events (Franks, 1963; Richardson, 1948). Unlike dancing with someone else, go-go presented opportunities for greater self-expression, individualism and improvisation. To some extent the dancer's wild gyrations could be interpreted as an energetic response to newfound freedom and a desire for physical expression of the sense of liberation. On the other hand due to the physical containment of girls - whether in cages or on raised podiums, the frantic movements also resemble those of trapped birds, desperate for a way out.

Perhaps go-go articulated a mixture of contradictory and conflicting emotions experienced by a generation of women, who were now expected to make choices their mothers and grandmothers would never have envisaged. American society no longer presented the straightforward path towards marriage and motherhood as the sole destination for young girls. With the prospect of alternative ways of living, go-go dancing presented an outlet to express feelings of uncertainty in a turbulent era of changing gender relations. Indeed, when explored within the wider context of partner dancing, elements of the style point to growing and unresolved division between the sexes towards the middle of the 1960s.

\section{The Demise of Partner Dancing}

Partner dancing always played a pivotal role in twentieth century courtship rituals but in the early 1900s, relationships were more likely to be established within the confines of the family home than the ballroom. Under the watchful eye of adults, young people's sexual behaviour could be closely monitored and parents were able to influence who their daughters might marry. In a study of twentieth century dating, Parker explains how the rationale underpinning these domestic encounters, was to secure a marriage.

During this time, few women were actually in the workforce; most were financially dependent on their parents or husbands. Marriage was the socially acceptable practice to ensure a woman the support she needed. While traditional courtship encouraged a man and 
woman to interact in an intimate setting, its purpose was to ensure a marriage contract for the benefit of both partners (Parker, 2005: 44).

She argues that the process of courting was initially, "a male-driven, asexual, and etiquetteconscious practice", only evolving when women began to acquire "sexual identities, which they had never had before, and the power to pursue men" (Parker, 2005). In this respect courtship and dating were somewhat different because as regards the former activity women had very little agency in decision-making.

Ultimately, decisions around selecting a partner fell to parents and the wider family because notions of romance were of less importance than economic and familial considerations. Custom dictated that if a man wished to commence a relationship he firstly: "'called upon' the woman in person to request her company, a social exchange that served the added purpose of providing parents with an opportunity to meet the suitor" (Turner, 2003: 7). As the century progressed however, relationships could be formed in more impersonal spaces such as theatres and dancehalls, at which point dance took on a more central role within courtship. In the social context of dating dancing with a partner allowed romance to flourish at a time when young people had little access to any private space for sexual experimentation. Furthermore they were able to get to know one another physically, in an embodied encounter and a prelude to greater sexual intimacy.

As in other areas of culture, the rules of social dancing were conditioned by the dynamics of gender, since the very act of entering into a dancehall as a couple, necessitated an unequal financial exchange. Market forces ensured that finding a partner became a competitive activity with economic implications, leading to the commodification of inter-war courtship, and because men earned more than women, they were expected to pay when taking a girl dancing. No doubt the men derived an degree of pleasure, both from the social 
experience and the challenge of learning to dance, however, Nott suggests that while men's primary motive on entering the dancehall was to find a partner, women are socially conditioned to enjoy dancing for its own sake (Nott, 2002:185). ii

Women had considerably less personal spending power than men but as McKibben (1998: 394) notes, their passion for dance could easily match the stereotypical male obsession with sport. Therefore, rather than missing out on such a pleasurable pastime, if they did not have a boyfriend, they would sometimes find a way to pay for themselves. A contemporary feature on ballroom etiquette reports young women saying: "we do not wait to be taken to a dance, but pay for our own ticket at the door, our own refreshments - if none are forthcoming" (Delany, 1926: 112). The desire to dance and a lack of finances, led some women to resort to more desperate tactics, compelling them to "hang about the entrance and hope that some bloke [would] pay for them" (Jephcott, 1942: 134). Once they gained admittance, rather than waiting for a man to invite them onto the dance floor, unaccompanied women could also use the services one of the professional, male dance partners.

\section{Dancing in the Context of Patriarchy}

Clearly, with or without a man for company and support, women thoroughly enjoyed the pleasure and escape offered by the ballroom and dancing with or without a male partner, and the resolute behaviour indicates a growing boldness and determination to pursue dance on their own terms. It also illustrates how women's desire for greater independence was mirrored in the cultural practices surrounding dancing. Although the feminine pursuit of dance was motivated by pleasure and escapism some observers interpreted the behaviour differently. In certain quarters this kind of ballroom behaviour was viewed as immoral as the following comment on ballroom behaviour from a Mass Observation report reveals. Reflecting on the attendant behaviour of the dancers, a respondent claims: "The sexual nature of dancing was obvious all the time. Why should the dancers dance in couples 
otherwise?" iii

It is easy to see why this conclusion might be drawn, because ballroom dance involves close physical contact, allowing opportunities to enjoy the sensual pleasure of bodily communication as well as the pleasure of moving as one across the dancefloor (Csikszentimhalyi, 1975). The physical proximity of dancing partners enabled men and women to experienced a degree of intimacy usually reserved for an established sexual partner. Nevertheless, men could take advantage of the situation since they were usually instigators of the proceedings. Clearly if a woman danced with a partner they found attractive, the experience could be pleasurable, but in the unwritten rules of ballroom dancing, refusing invitations was frowned upon.

Even if the erotic overrtones of the union outweighed recognition of the fact, both parties were participating in an institutional process designed to reinforce inequality. As they were not the initiators of the dyad, women were under pressue to accept unwanted requests and had to endure any physical contact arising thereupon. In the context of patriarchal politics, partner dance articulated the dynamics of traditional gender relations, notably the dominance of men over women and girls (Marion, 2008).

Although patriarchy generally describes male domination of the public and private sphere, it also relates to subtler expressions of power as seen in ballroom dancing, where men have greater control. The assumption is that women will automatically follow in the same direction as the leader, and a failure to do so, is indicative of an inadequate 'follower'. On the one hand, leading could be perceived a benign role, in that if the couple are to progress effectively across the floor, one or other partner needs to direct the sequence of steps. However, as Beggan and Pruitt argue, "By assigning men the role of 'lead' and women the role of 'follow', social dance can be viewed as a form of serious leisure that appears to perpetuate a system that positions women as subordinate to men" (Beggan and Pruitt, 2014: 508). 
In the dancehall environment a woman could avoid relying on a man financially and socially but unless they danced with members of their own sex, they still had to submit to the agency of the male leader, rendering them subordinate throughout the duration of the dance. Moreover, as Ehrenreich (2007:212) argues, unlike subsequent, more individualized dance styles, like the Twist, ballroom dance permits "little group interaction or individual variation" to break up the leader/follower dynamic. As initiators and controllers of the dance, men not had opportunities to force themselves upon a reluctant partner, they could also take advantage of their power as leaders by holding a female partner too closely or directly her too forcefully, ${ }^{\text {iv }}$

Despite the fact that men had more opportunities to exploit physical intimacy on the dancefloor, throughout the 1930s and 1940s, social concerns about the unwanted consequences of dancing continued to be directed towards women. This is particularly the case regarding dancing's potential to corrupt, expressed in the view that it would "wreak havoc on the morals and sexual development of women and girls [and] threaten their roles as the keepers of domestic sanctity of home and hearth, or tempt their susceptible sexual natures" (Malnig, 2009: 73). By spending too much time in a ballroom women risked not only their reputation but their future capacity to become respectable housewives and mothers.

\section{Changing Social Roles and New Dance Styles}

Concerns about the corrupting potential of dance tell us less about moral laxity than they do about the impact of female emancipation on gender relations at the time. Then as now, the rules of ballroom dancing clearly failed to mirror changing gender roles at a time when women were becoming more independent. Even if this wasn't reflected on the dancefloor, during the period in question they were taking on, " new roles in the public world, and ideas about what was appropriate behaviour for men and for women shifted gradually or were jolted into new configurations" (Bailey, 2013). In the Second World War for example, women fulfilled roles traditionally carried out by men: working in 
manufacturing, driving heavy vehicles and demonstrating their capability as competent employees and breadwinners. Yet the situation was quickly reversed when men returned from the front line, at which point female workers were expected to give up their employment to become full time wives and mothers again.

Having had a taste of freedom, most were reluctant to do so, and some women were now sufficiently independent to run their homes without the support of a male partner, As Julie Summers writes:

For women who worked during the war readjustment to life in the post war era was difficult. New found independence, both financial and emotional, had an impact on relationships and created expectations on both sides that could not always be fulfilled (Summers, 2009: 141).

Gell (1985) suggests, styles of movement adopted by dancers may differ to some extent from the rules and realitieis of everyday life, but still refer back to them symbolically and the dances of the day did eventually begin to reflect the shifting character of gender relations. Women's liberation was some way off but a new wave of swing dance moves provided a "semiotic modality" that elided spoken expression (Farnell, 2012: 9).

In the late 1930s and early 1940s, dances like the Lindy Hop and Jitterbug replaced earlier 'close hold' dance styles, expressing female emancipation metaphorically by allowing brief interludes of separation from male partners. In both dances men still took the lead, but there were subtle changes in that: "women were able to improvise with the introduction of the swing-out and both partners [could] dance as equals" (Smith, 2008: 2). ${ }^{\mathrm{v}}$ Within the eight count swing-out figure of Lindy Hop, the couple would commence the dance together in a ballroom position until the man flung his partner away so that he could improvise briefly. Similarly, the Jitterbug speeded the rhythm up to a count of six beats, incorporating 'breakaways' which offered both partners room for improvisation,

Without the firm control of a male leader the proceedings were too unpredictable for those used to traditional ballroom patterns of movement. On the dancefloor the Jitterbug illustrated a growing distance between men and women and to some observers, the heightened rhythmic 
emphasis of the new wave of swing dances was little more than 'degenerate' (Scheurer, 1989: 155). However, even raunchier styles of music and dance were just upon the horizon. By the late 1940s the popularity of the big bands faded to be supplanted by rock and roll combos, playing a style of music blamed by one observer for "the unleashing of generations of repressed sexuality" (Pratt,1990:140)

Evolving from swing and jazz dancing, The Jive was well suited to the emergent genre and after the release of Rock Around the Clock in 1955, the dance ignited considerable interest among teenagers. Most were conditioned to dancing around jukeboxes in cafes rather than going to ballrooms but the dance maintained some elements of the leader/follower pattern and in this respect it could be seen as representing womens' return to reliance on men socially and economically in 1950s. Nevetheless, at least the jive offered latitude for improvisation and growing elements of individuality: in the words of a seasoned exponent, "we just did it, everyone had their own style, it didn't matter how you did it" (Nott, 2015:119).

\section{Semi-Solo Dance of the 1960s}

By the 1960s a growing chasm on the dance floor between male and female dancers demonstrates the activity's capacity to reveal social and cultural realities. Ehrenreich suggests that rather than following the European tradition of formal partner dance these new ways of dancing had more in common with ancient ecstatic religious traditions. She points out how although the jive prevailed towards the mid 1960s, as popular music evolved, "people began to move to it more freely, dancing individually or in lines and circles. A person might get up and start dancing alone, another might follow, women might dance with women, men with men, couples might dissolve and re-form" (Ehrenreich, 2007: 215).

The new dances mapped closely onto the an emergent youth culture as youth culture at a time when women demanded even greater freedom and a break with convention. The Twist was the first of a wave of similar dances which rejected formal steps and partner holds. In The Twist and related dances such as The Watusi, The Mashed Potato, The Shake and The 
Hitch Hike, dancers occupied a shared space,sometimes even facing their partners, but points of contact were limited. Indeed Time magazine reported that when twisting "the dancers scarcely ever touch each other or move their feet" (Denisoff and Romanowski, 1991: 111).

A contemporary film shows President Johnson's daughter Luci dancing at a 'Young Citizens for Johnson' party in Beverley Hills with the actor Steve McQueen. As the couple dance they face towards one another from time to time but do not engage in any bodily contact while gyrating and swivelling their hips. ${ }^{\mathrm{vi}}$ Another film clip from the period shows a representative from The Arthur Murray dance studios offering UK viewers a demonstration, teaching them how to dance The Twist. ${ }^{\text {vii }}$ After showing basic steps a team of dancers twist in pairs, essentially mirroring one another - but it is clear from the clip that the notion of leading and following was undermined as neither partner appears to dictate the direction of the dance. Instead movement up and down or side to side, is negotiated informally, illustrating the discursive potential of dance at a time where women were no longer prepared to submit to the absolute authority of men.

\section{Post-War Society and the American Dream}

The changing styles of movement in these semi-solo dances articulate the increased emphasis on individual freedom and personal autonomy which characterized much of the 1960s. Lukes suggests that American society has always been founded upon the concept of individualism and "all that has at various times been implied in the philosophy of natural rights, the belief in free enterprise, and the American Dream." (Lukes, 1973:26). During the 1950s and early 1960s the nation experienced unprecedented economic growth, leading to a buoyant consumer culture and increased home ownership. Ensuing prosperity fuelled even greater levels of individualism seen in the 1960s when consumer-oriented lifestyles took hold.

Whereas previous generations of Americans, forced to endure considerable economic hardship had to rely on family and neighbours for social support, after WWII the upswing in 
the economy created increased leisure time and less reliance on relatives or friends. American families could enjoy consumer goods such as washing machines, cars and televisions, products beyond reach during the 1940s when rationing still prevailed. The distinction was summaried by the economist J. K Galbraith in the book The Affluent Society where he said: "the ordinary individual has access to amenities - foods, entertainment, personal transport, and plumbing - in which not even the rich rejoiced a century ago" (Galbraith, 1998: 2). The affluent middle, and aspirational working-class families of the 1950s onwards, experienced very different lives to those of their predecessors. No longer needing to live side by side with the extended family and with rising divorce figures, family units were less stable than they had been.

For women the social and economic changes were more pronounced. Marriage at least provided them with much needed financial security, but the union was dependent on giving up the chance to earn a livelihood in exchange for providing unpaid labour as housewives and mothers. The newfound availability of domestic technology and widening access to capital goods effectively reduced the amount of time required to run a house, leaving them with spare time. This meant women had increased time to spend on leisure or working outside the home, reducing the incentives to get married or start a family in the first place, making divorce more optional (Greenwood and Guner, 2009: 233).

The second wave of feminism in the 1960s ensured that life no longer had to revolve as much around finding a man, marrying and producing children. Initially the battle centred around discrimination in the workplace in the workplace: following a Presidential Commission on the Status of Women, the signing of an Equal Pay Act in 1963 helped to close the gender gap in both income and opportunities. ${ }^{\text {viii }}$ Women's rights continued to advance with the founding of a National Organization for Women with its mission to promote diversity, while tackling access to birth control, lesbian rights, violence towards women and equality under the law. 


\section{"I want something more than my husband and my children and my home"}

Despite living in materially comfortable circumstances, married women started to question the meaning of their circumscribed lives as wives and mothers. The publication of Betty Friedan's polemic The Feminine Mystique in 1963 documented the growing dissatisfaction of generation of American women. Friedan urged them to respond to the inner voice telling them, "I want something more than my husband and my children and my home" (Friedan, 1963: 29). From the mid-1960s rising divorce statistics suggest that for some women autonomy involved abandoning an unhappy marriage regardless of how risky it would be to go it alone (Heer and Grossbard-Shechtman, 1981: 49). According to Heale (2001: 13) calls for personal freedom and a desire to find meaning found expression in new sexual attitudes and for growing numbers of women, this meant a rejection of traditional rules governing relationships. ${ }^{\text {ix }}$

\section{Youth Culture and the Sexual Revolution}

With an extended window of time between leaving school and finding a job, young women now had a period of time where they could make decisions about matters relating to employment and relationships. Some experimented with the lifestyle choice of living alone while others experienced a variety of relationships before eventually settling down. The new lifestyles coincided with and were supported by a post-war youth culture equally determined to challenge traditional American values in all directions. Described as “a community of like-minded anti-establishment, anti-war, pro-rock'n'roll individuals, most of whom had a common interest in recreational drugs" (Miles, 2011), the younger generation saw peace and sexual experimentation as more important than pursuing The American Dream or joining the rat race. The young Americans' personal experience of life differed significantly from that of their paents, notably in terms of political and economic frames of references. Whereas parents and grandparents had lived through the years of the Great Depression and a major world war, working hard just to survive, the 'baby boom' teenagers 
had limited personal experience of poverty. As a result, they were unfamiliar with notions of self-restraint. Without experience of the horrible realities of war the young were determined to break rules established by their parents by rejecting materialism, preferring the mantra "Make Love Not War" to joining the military.

On the surface the emphasis on the frivolous enjoyment of sex seems innocent enough and a superficial reading suggests a homology with the ideology of feminism and the call for greater freedom. However with hindsight young women were not always the main beneficiaries of the sexual revolution, making the freedoms extolled somewhat questionable. As well as influencing the regulation of sexual behaviour, the sexual revolution of the 1960s introduced, "changes that helped to mold contemporary sexual attitudes and behaviours: a shift in relations between men and women [and] the continuing and accentuating commercialization of sex" (Turner, 2003: 14).

Undoubtedly this led to conflicts which were not easy to resolve. On the one hand: "Some student radicals used the term [sexual revolution] specifically to refer to end of the 'tyrany of the genital' and the arrival of an eagerly awaited age of polymorphous pansexuality" (Allyn, 2001:5). Yet men were much more at liberty to enjoy the social sanctioning of casual sex and the sexual freedom may have been overstated, because for girls, the risk of unwanted pregnancy was still a source of anxiety. ${ }^{\mathrm{x}}$ It was difficult for unmarried women to find a doctor who would prescribe the Pill, therefore they still faced the prospect of pregnancy and possibly venereal disease. ${ }^{\mathrm{xi}}$ Before long young feminists started to equate the so called sexual revolution with the oppression and objectification of women.

At least in the 1950s, women had been able to defend their honour by refusing to engage in sex before marriage, safe in the knowledge that both parties accepted the risks inherent in pre-marital sex. As a result "teenage girls were in constant fear of 'going all the way', or worse, appearing to have, as public opinion was obsessed with female virginity until marriage" (Mlakar, 2008: 12). Since men were expected to marry a pregnant girlfriend, 
virginity was a powerful and socially respected form of currency, giving the woman a valid reason to refuse a sexual advance. With the newfound emphasis on sexual freedom it was harder for women to say no, and without the bargaining power of virginity, the long term prospect of a marriage could not be guaranteed.

\section{Go Go Dancing, Anxiety and Rise of Individualism}

To a certain degree go-go dancing did resonate with the overall mood of liberation and equality. By dancing alone, no longer relying on the support of a male partner, the girls appeared to endorse the newfound independence and sexual freedom but their solo performances also speak of an individualism which was lacking in semi-solo dances of the early 1960s. In this respect go-go mirrors the shift in American society's social organization as it moved from a traditional and community based structure of the 1930s and 1940s towards the more personalized, self-reliant lifestyles which followed.

According to the sociologist David Riesman, one of the consequences of the move was a tendency to become less reliant on sources of authority such as the church and the government for guidance. In The Lonely Crowd (1951) he argued that societies could be defined as 'inner' or 'outer' directed, depending on the dominant social structure. The innerdirected communities of the pre-war period were characterized by close-knit communities, adherence to tradition and people knew what wasexpected of them because authority was unequivocal. The values were internalized because,"The inner-direction person has early incorporated a psychic gyroscope which is set going by his parents and can receive signals later on from other authorities who resemble his parents" (Riesman, 2001: 24). The customs and authority of previous generations went unchallenged because people accepted established moral and social principles without feeling the need to question them. In the 'other-directed' 1960s however, sources of authority became more diffuse when young people looked outwards towards ambiguous sources for direction. With weaker connections to the extended family, other-directed youth looked beyond the local community and the church - turning instead to alternative religions and communities for support and guidance. 
The paradox within the oxymoron 'Lonely Crowd' captures the mood of a teeming throng whose members are alone, and the concept of lonliness within the crowd certainly resonated with experience of women, no longer cushioned by the presence of the extended family or guaranteed a place within society as wives and mothers.

Not everyone was at east with the advent of women's liberation for as Riesman points out, the eclectic cosmopolitianism of the post-war period had created a generation who were "at home everywhere and nowhere, capable of rapid, if sometimes superficial intimacy with and response to everyone" (Riesman, 2001:25). Without the certainty of marriage and family life, young people lacked the stability and security of knowing where they were going. This uncertainty found physical expression in go-go dance where the absence of any formal pattern of steps mirrored the experience of a life without clear direction. On the surface, the scanty outfits communicated a message of sexual liberation at a time when more opportunites for intimacy than ever before were presented. However the dancers' frantic gyrations connote the anxiety of women facing an ill-defined future.

Earlier in the 1960s, young men and women seemed united in the pursuit of greater equality: a unity expressed physically as they mirrored one another's moves, side by side in semi-solo dances. While they remained physically separate, at least they were a recognisable pair, inhabiting a shared space. With the advent of solo, go-go style dancing, the girls appear isolated, disconnected from the wider world: free to please themselves but with no idea where they might go next.

Girls no longer faced pressure to get married and therefore did not require the symbolic guidance and control of a male partner - but at the same time the institution of marriage itself was under threat. In the US the divorce rate almost doubled from the 1900 s to the 1960 s, shattering faith in the stability of family life and motherhood. Dancing go-go style offered a symbolic outlet for their dilemma. The girls' erotic movements performed their availability yet the caged performances simultaneously signified the dancers' unavailability. Moreover 
apparent freedom on the podium was compromised by physical containment. Unable to resolve the contradictions, the frantic gyration of go-go girls connotes the anxiety of birds, desperate to escape, but unsure how they would survive if they did.

\section{References}

Allyn, D. (2001). Make Love Not War: The Sexual Revolution - An Unfettered History. Boston: Little, Brown and Co.

Austen, J. (2007). TV-a-Go-Go. Chicago: Chicago Review Press.

Bailey, B. (2013) From front porch to back seat: Courtship in twentieth-century America, Baltimore and London: John Hopkins University Press (ebook)

Beggan, J. and Pruitt, A. (2014). Leading, following and sexism in social dance: change of meaning as contained secondary adjustments. Journal of Leisure Studies, 33(5), pp.508-532. Csikszentmihalyi, M. (1975).Beyond boredom and anxiety. San Francisco, CA: Jossey-Bass. Denisoff, R. and Romanowski, D. (1991) Risky Business: Rock in Film, Piscataway: Transaction.

Delany, N. (1926). Jazz Manners in the Ball-room. Popular Music and Dancing Weekly, p.112.

Ehrenreich, B. (2007) Dancing in the Streets: a History of Collective Joy,London: Granta Books.

Farnell, B. (2012) Dynamic Embodiment for Social Theory: "I Move Therefore I Am", London: Routledge.

Franks A.H. (1963) Social dance: a short history. Routledge \& Kegan Paul: London. Friedan, B. (1963) The Feminine Mystique, New York: W.W. Norton and Co. Galbraith, J. K. (1998) The Afflient Society,New York: Houghton Mifflin. Gell, A. 1985. 'Style and Meaning in Umeda Dance', in P. Spencer (ed.), Society and the Dance. Cambridge: Cambridge University Press, pp.183-205 go-go. (2017). In: Oxford English Living Dictonary. [online] Available at: https://en.oxforddictionaries.com/definition/us/go-go [Accessed 30 Jul. 2017]. go-go-go. (2017). In: Oxford Living Dictionary, 1st ed. [online] Oxford: Oxford University Press. Available at: https://en.oxforddictionaries.com/definition/go-go-go [Accessed 7 May 2017].

Goldin, C. and Katz, L. (2002). The Power of the Pill: Oral Contraceptives and Women's Career and Marriage Decisions. Journal of Political Economy, 110(4), pp.730-770.

Greenwood, J. and Guner, N. (2009). Marriage and Divorce since World War II: Analyzing the Role of Technological Progress on the Formation of Households. In: D. Acemoglu, K. Rogoff and M. Woodford, ed., NBER Macroeconomics Annual 2008, Volume 23, 1st ed. Chicago: University of Chicago Press, pp.231-276.

Heale, M. (2001). The Sixties in America: History, Politics and Protest. Edinburgh: Edinburgh University Press.

Heer, D. and Grossbard-Shechtman, A. (1981). The Impact of the Female Marriage Squeeze and the Contraceptive Revolution on Sex Roles and the Women's Liberation Movement in the United States, 1960 to 1975. Journal of Marriage and the Family, 43(1), p.49-65.

Hunt, K. "Elmer Valentine Obituary", The Guardian 2009. Web. 2 June 2017

Jephcott, A. (1942) Girls Growing Up, London: Faber.

Kamp, D. (September 4, 2006). "Live At The Whisky". Vanity Fair 
Kamp, D. (2006). DavidKamp.com. [online] Live at the Whisky. Available at: http://davidkamp.com [Accessed 28 Jul. 2017].

Kennedy, J. (2015) The Young-Girl in Theory. Women \& Performance: a journal of feminist theory, 25 (2), pp. 175-194,

Lukes, S. 1973. Individualism. Oxford: Blackwell.

Malnig, J. (2009). Women, Dance, and New York Nightlife. In: J. Malnig, ed., Ballroom

Boogie, Shimmy Sham, Shake: A Social and Popular Dance Reader. Urbana: University of

Illinois Press, pp.72-90.

Marion, J. S. (2008).Ballroom: Culture and costume in competitive dance. New York, NY:Berg.

Mass Observation Archive (1938-41), Topic Collection 38: Music, Dancing, and Jazz

McKibbin, R. (1998) Classes and cultures: England, 1918-1951, Oxford: Oxford University Press.

McLellan, D. (December 7, 2008). "Elmer Valentine, co-founder of Whisky a Go Go, dies at 85". Los Angeles Times. pp. B11.

Miles, B. (2011). Spirit of the underground: the 60s rebel. The Guardian. [online] Available at: https://www.theguardian.com/culture/2011/jan/30/underground-arts-60s-rebel-

counterculture [Accessed 31 Jul. 2017].

Mlakar, H. (2008) Merely Being There Is Not Enough: Women's Roles in Autobiographical Texts by Female Beat Writers, Boca Raton: Universal Publishers.

Nott, J. (2002) Music for the People: Popular Music and Dance in Interwar Britain.

Oxford: Oxford University Press.

Nott, J. (2015) Going to the Palais: A Social and Cultural History of Dancing and Dance, Oxford: Oxford University Press

Parker, K. (2005). An Examination of Courtship and Dating from 1900 through the 1950s.

Aegis: The Otterbein Humanities Journal, 10, pp.44-54.

Perrone, P. (2009). Elmer Valentine: Promoter behind Los Angeles' Whisky a Go Go and Roxy clubs. The Independent. [online] Available at:

http://www.independent.co.uk/news/obituaries/elmer-valentine-promoter-behind-los-angeleswhisky-a-go-go-and-roxy-clubs-1653334.html [Accessed 6 May 2017].

Polhemux, T. (1995). Dance, Gender and Culture. In: H. Thomas, ed., Dance, Gender and

Culture. Basingstoke: Palgrave, pp.3-15.

Pratt, R. (1990) Rhythm and Resistance: Explorations in the Political Uses of Popular Music,

Westport: Praeger.

Richardson P. (1948) The history of English ballroom dancing (1900-1945). London:

Jenkins.

Riesman, D. (1951) The lonely crowd, New Haven: Yale University Press.

Reisman, D. (2001) The lonely crowd: A Study of the Changing American Character, Abridged and Revised Edition, New Haven: Yale University Press.

Scheurer, T. (1989). American Popular Music: The nineteenth century and Tin Pan Alley.

Bowling Green, Ohio: Bowling Green State University

Smith, B. (2008) The Oxford Encyclopedia of Women in World History, Oxford: Oxford

University Press.

Summers, J. (2009) Stranger in the House: Women's Stories of Men Returning from the

Second World War, London: Simon and Schuster.

The Twist (1992) dir. Ron Mann

Vincent, T. (1979). The complete encyclopedia of television programs, 1947-1979. 1st ed.

South Brunswick: Barnes.

https://deepblue.lib.umich.edu/bitstream/handle/2027.42/63821/aabra_1.pdf 
Mish, Frederic C., Editor in Chief Webster's Ninth New Collegiate Dictionary Springfield, Massachusetts, 1984--Merriam-Webster Page 525. Turner, Jeffrey (2003) Dating and Sexuality in America: A Reference Handbook, New York: ABC Clio.

' Other fashions worn by go-go dancers were mini dresses, tank tops, tight shorts and calf length boots (nicknamed go-go boots). Long hair tied up in bunches at the side increased visual appeal when the girls shook their heads.

ii Dancehalls also created highly valued employment opportunities for women as dance partners, waitresses and cloakroom assistants.

iii Mass Observation Archive: TC 38/1/A, Locarno, April 27, 1939.

iv Although women have some influence over the encounter, such as deliberately breaking the rules by failing to follow the lead they are given, this could lead to rejection by other partners and most women dread being singled out as a 'wallflower'.

${ }^{\vee}$ Both dances are characterised is by movement between open and closed positions in the swing-out.

vi See: https://www.youtube.com/watch?v=L8r-tAM54H0

vii https://www.youtube.com/watch?v=ETX03Zjtarc

viii In 1961 The Presidential Comission on the Status of Women was established by John F. Kennedy to examine issues regarding women's equality.

${ }^{\mathrm{ix}}$ In particular the founding of The Daughters of Bilitis (DOB) in 1955 presented an affront to traditional and patriarchal ideas about relationships. Although originally a social group the DOB evolved into a political organisation fighting for acceptance of lesbianism.

${ }^{x}$ The provision of contraceptive services to unmarried women younger than 21 years was highly circumscribed before the late 1960s (Goldin and Katz, 2002: 739).

xi The following case indicates that free access to birth control was some way off: "The Supreme Court (in Griswold v. Connecticut) gave married couples the right to use birth control, ruling that it was protected in the Constitution as a right to privacy. However, millions of unmarried women in 26 states were still denied birth control" (Source: http://www.ourbodiesourselves.org/health-info/a-brief-history-of-birth-control/). 